\title{
STENOTROPHOMONAS MALTOPHILIA AS A CAUSATIVE AGENT OF CHRONIC RESPIRATORY DISEASE IN SCOTTISH FOLD TOMCAT: A CASE REPORT
}

\author{
Erdem Gülersoy $^{1 *}$, Büşra Burcu Erol ${ }^{2}$
}

${ }^{1}$ Department of Internal Medicine, Faculty of Veterinary Medicine, Harran University, Şanlıurfa, Türkey

${ }^{2}$ Department of Internal Medicine, Faculty of Veterinary Medicine, Selçuk University, Konya, Türkey

\section{*Corresponding author:}

Dr.sc. Erdem Gülersoy

Adress: Harran University,

Faculty of Veterinary Medicine,

Department of Internal Medicine, 63200 Eyyübiye Campus, Şanlıurfa,

Türkey

Phone: +905333344042

ORCID: 0000-0001-8511-0150

E-mail: egulersoy@harran.edu.tr

Original submission:

27 July 2021

Revised submission:

13 October 2021

Accepted:

22 October 2021

\begin{abstract}
Sneezing and nasal discharge are common in cats with respiratory diseases. Bacterial, viral and fungal agents are included in the etiology of respiratory diseases. Although Stenotrophomonas maltophilia (S. maltophilia) is accepted as a harmless commensal and a colonizer due to its actions that are not enough to initiate neither an immune response nor clinical symptoms, it was isolated from animals with chronic respiratory disease. In this case report, identification and treatment of $S$. maltophilia in a cat with chronic respiratory disease, whose treatment was not successful with the use of empirical antibiotics, were presented. The physical examination of the cat revealed normal vital signs and prominent bilateral mucopurulent nasal discharge. No abnormal blood analysis results were observed except mild respiratory acidosis, lymphocytosis and elevated alkaline phosphatase enzyme activity. After ruling out fungal factors and systemic viral infections, the agent was identified on the basis of aerobic culture. A complete recovery was achieved by the treatment protocol including secretolytic (ambroxol, $1 \mathrm{mg} / \mathrm{kg}$ ), decongestant (oxymetazoline, 0.05\%) and antibiotic (enroflaxacin, $5 \mathrm{mg} / \mathrm{kg}$ ) administrations based on the antibiogram results performed by the disc diffusion method (Mueller-Hinton Agar). All follow-up clinical and blood parameters were within reference ranges. Therefore, it was concluded that $S$. maltophilia should be considered in the etiology of persistent, antibiotic-resistant chronic respiratory diseases of cats, and that an antibiogram and agent identification are important in establishing the final diagnosis.
\end{abstract}

Keywords: Cat, chronic respiratory disease, colonizer, Stenotrophomonas maltophilia, treatment 


\section{INTRODUCTION}

Diseases affecting the nasal cavity and nasopharynx, with clinical symptoms of sneezing and nasal discharge, can be caused by various infections, chronic rhinosinusitis, foreign bodies, dental caries, neoplasia, polyps and traumas (Henderson et al., 2004; Demko and Cohn, 2007). Although chronic serous discharges are mostly of viral and allergic etiology, mucopurulent nasal discharge is associated with inflammation, primary bacterial or fungal disease or overgrowth of normal bacterial flora (Quimby and Lappin, 2009). While unilateral nasal discharges are mostly seen in the presence of foreign body oronasal fistula and neoplasia, bilateral discharge is non-specific and can be observed in almost any etiology (Henderson et al., 2004). Viral agents associated with sneezing and nasal discharge in cats are mainly Feline herpesvirus (FHV-1) and Feline calicivirus (FCV) (Richter et al., 2009). Bacterial agents considered as primary respiratory pathogens are Bordetella bronchiseptica, Chlamydophila felis, Streptococcus canis, Mycoplasma spp., Corynebacterium spp., Escherichia coli, Pasteurella multocida, Pseudomonas aeruginosa, Streptococcus viridans, and Staphylococcus intermedius (Bannasch and Foley, 2005; Quimby and Lappin, 2009). Cryptococcus neoformans and Aspergillus spp. are the most common fungal agents in feline upper respiratory tract diseases (O'Brien et al., 2004). In addition, flat-faced breeds such as British Shorthairs, Persians, Himalayans and Scottish Folds have a predisposition to upper respiratory infections because of their facial anatomy (Kornreich et al., 2012).

Stenotrophomonas maltophilia (S. maltophilia) is a Gram-negative, oxidase-negative rod bacterium that is very common in soil, plants, ponds and sewers (Denton and Kerr, 1998). It has been reported that $S$. maltophilia has been isolated from many animal species (Cloud-Hansen et al., 2007). In one study, S. maltophilia was isolated from 3 horses, $1 \mathrm{dog}$ and 1 cat with chronic respiratory disease (Albini et al., 2009). Subsequently, it was isolated as a probable casual agent from a buffalo with pyogranulomatous hepatitis (Petridou et al., 2010). Also, it has been reported that it was isolated from the urinary bladder wall of 3 dogs with chronic urological problems (KralovaKovarikova et al., 2012).

In humans, $S$. maltophilia is frequently isolated in chronic respiratory diseases such as cystic fibrosis and chronic obstructive pulmonary disease (Denton and Kerr, 1998; Albini et al., 2009). Nevertheless, there are few reports on animals. Therefore, S. maltophilia is defined as a harmless commensal and a colonizer due to its inability to initiate an immune response and clinical symptoms in animals (Denton and Kerr, 1998; Henderson et al., 2004).

For this reason, in this case report, the clinical presentation and treatment of $S$. maltophilia infection in a cat with chronic respiratory disease characterized by sneezing and both nasal and ocular discharge is presented.

\section{CASE PRESENTATION}

An 8-month-old, non-neutered, mostly indoor Scottish Fold male cat, regularly vaccinated (feline core vaccines including FHV-1, FCV, FPV, rabies, and FeLV) was brought to Harran University Veterinary Faculty Animal Hospital Internal Medicine Department with complaints of inappetence, sneezing, nasal and ocular discharge. The owner was consented to use the analysis results for research and publication purposes. History revealed that the cat was previously brought to a private veterinary clinic with the same complaints 
(a month before) and treated empirically with 5 $\mathrm{mg} / \mathrm{kg}$ of clavulanic acid, amoxicillin trihydrate, SID, (Synulox ${ }^{\circledR}$, Zoetis), $1 \mathrm{mg} / \mathrm{kg}$ of maropitant, SID, (Cerenia ${ }^{\circledR}$, Zoetis), $70 \mathrm{mg} / \mathrm{kg}$ of n-acetyl cysteine, BID, (Asist ${ }^{\circledR}$, Bilim Pharmaceuticals) and oxygen therapy with nasal cannula for thirty minutes twice a day, for a week.

Physical examination revealed no discrepancies (body temperature: $39^{\circ} \mathrm{C}$, heart rate: 140 beats/ min, respiration rate: 64 breaths $/ \mathrm{min}$ ). Mandibular lymph nodes were both enlarged and painful. Other palpable lymph nodes were painless and of normal size. It was determined that the both nasal and ocular discharge were bilateral and mucopurulent. For further diagnosis, blood analysis, rapid diagnostic antigen test applications and imaging techniques were used. Seven mililiters of venous blood sample was taken by vena cephalica venepuncture with minimal restraint in order to minimize stress. Blood samples were used for hematology (using tubes with $\mathrm{K}_{3}$ EDTA, MS4® Melet Schloesing Auto Analyzer, France), biochemistry (using tubes with clot gel coagulant, BT 3000 Plus ${ }^{\circledR}$ Biotecnica Instruments S.p.A Italy), blood gases (using tubes with heparin, ABL90 Flex Plus ${ }^{\circledR}$ Radiometer blood gas analyzer, Denmark) analysis as well as for specific rapid tests (Feline Calicivirus antigen, FCV Ag; Feline Herpesvirus antigen, FHV Ag; Feline Immunodeficiency Virus antibody/Feline Leukemia Virus antigen, FIV Ab/FeLV Ag and Feline Parvovirus antigen, FPV Ag (Asan Pharm ${ }^{\circledR}$, Korea)). After the blood sampling, thoracic x-ray was taken. In addition, microscopic examination of the smear prepared from the venous blood sample was performed to investigate for the presence of any blood parasites (Giemsa staining, x1000 magnification with immersion oil, Olympus ${ }^{\circledR}$, light microscope, USA). Furthermore, a sterile swab of nasal discharge was sent to a commercial laboratory for fungal and bacterial culture as well as for antibiogram.

On the first admission, the results of all rapid tests were negative. Blood smear was examined for Cytauzxoon felis, Haemobartonella spp. and Anaplasma spp. and found to be negative. No abnormality was detected in the thoracic x-ray of the cat (Figure 1A). Blood gas analysis revealed a decrease in partial oxygen pressure and oxygen saturation $\left(\mathrm{pO}_{2}: 41\right.$, satO $\left._{2}: 76\right)$ and an increase in partial carbon dioxide pressure $\left(\mathrm{pCO}_{2}: 44\right)$. Accordingly, a slight decrease in blood $\mathrm{pH}(\mathrm{pH}$ : 7.33) was determined as respiratory acidosis. Other parameters were within the reference range. There were no discrepancies from the reference range in any hematology parameter except lymphocytosis (Lym \#: 6.68). No abnormality was observed in serum biochemistry, except for the increase in alkaline phosphatase enzyme activity (ALP: 121 $\mathrm{U} / \mathrm{L}$ ). The results of blood gases, hematology and serum biochemistry analysis which were performed on the first admission are presented in Table 1. 
Table 1 Blood gases, hematology and serum biochemistry results (first admission)

\begin{tabular}{|c|c|c|c|c|c|c|c|c|}
\hline \multicolumn{2}{|c|}{ Blood Gases } & \multirow{2}{*}{$\begin{array}{l}\text { Reference* }^{*} \\
7.35-7.45\end{array}$} & \multicolumn{2}{|c|}{ Hematology } & \multirow{2}{*}{$\begin{array}{c}\text { Reference } \\
5.0-19.0\end{array}$} & \multicolumn{2}{|c|}{ Serum Biochemistry* } & \multirow{2}{*}{$\begin{array}{c}\text { Reference } \\
4.7-14.3\end{array}$} \\
\hline pH & 7.33 & & WBC $10^{9} / \mathrm{L}$ & 12.43 & & $\mathrm{BUN} \mathrm{mg} / \mathrm{dL}$ & 13.7 & \\
\hline $\mathbf{p O}_{2}$ & 41 & $46.0-55.0$ & Lym\# 109/L & 6.68 & $0.2-5.7$ & Creatinine & 0.6 & $0.8-1.80$ \\
\hline $\mathrm{pCO}_{2}$ & 44 & $29.0-42.0$ & Mon \# 109/L & 0.96 & $0.1-1.1$ & AST U/L & 84 & $10-100.00$ \\
\hline satO $_{2}$ & 76 & 36 & $\mathrm{G}$ & 4.79 & 5.2 & $A$ & 121 & 0.00 \\
\hline $\mathrm{K} \mathrm{mmol} / \mathrm{L}$ & 3.8 & $3.4-5.6$ & $\mathrm{RBC} 10^{12} / \mathrm{L}$ & 6.89 & $4.0-9.0$ & ALT U/L & 51 & $10-80.00$ \\
\hline $\mathrm{Na} \mathrm{mmol} / \mathrm{L}$ & 157 & $150-165$ & MCV fl & 51.4 & $35.5-55.0$ & Albumin $\mathrm{g} / \mathrm{d}$ & 2.9 & $2.1-3.90$ \\
\hline $\mathrm{Cl} \mathrm{mmol} / \mathrm{L}$ & 127 & $104-$ & $\mathrm{MC}$ & 16.2 & 16.0 & Tri & 112 & $10-114$ \\
\hline $\mathrm{Lac} \mathrm{mmol} / \mathrm{L}$ & 1.1 & $0-2$ & $\mathrm{MCH}$ & 28.6 & $28.0-40.0$ & T. protein $\mathrm{g} / \mathrm{dL}$ & 5.4 & $5.4-7.80$ \\
\hline $\mathrm{BE} \mathrm{mmol} / \mathrm{L}$ & -5.3 & $-4-4$ & Hct & 25.4 & $24.0-45.0$ & Cholest. mg/dL & 139 & $90-205.0$ \\
\hline $\begin{array}{l}\mathrm{HCO}_{3} \\
\mathrm{mmol} / \mathrm{L}\end{array}$ & 21.5 & $19-24$ & RDW & 9.3 & $8.0-12.0$ & Glucose $\mathrm{mg} / \mathrm{dL}$ & 140 & $64-170$ \\
\hline
\end{tabular}

pH: Power of hydrogen, pO2: Partial pressure of oxygen, pCO2: Partial pressure of carbon dioxide, satO2: Oxygen saturation, K: Potassium, Na: Sodium, Cl: Chlorine, Lac: Lactate, BE: Base excess, HCO3: Bicarbonate, WBC: White blood cells, Lym: Lymphocytes, Mon: Monocytes, Gra: Granulocytes, RBC: Red blood cells, MCV: Mean corpuscular volume, MCH: Mean corpuscular hemoglobin, MCHC: Mean corpuscular hemoglobin concentration, Hct: Hematocrit, RDW: red cell distribution width, BUN: Blood urea nitrogen, AST: Aspartate aminotransferase, ALP: Alkaline phosphatase, ALT: Alanine aminotransferase, Trig: Trigylcerides, T.protein: Total protein, Cholest: Cholesterol. Units and reference values are based on *Klaassen, 1999 and $\ddagger$ Moritz et al., 2004

Due to financial concerns of the owner, polymerase chain reaction (PCR) analysis could not be performed. The agent identification was made using an aerobic culture (BD Bioscience ${ }^{\circledR}$, New Jersey, USA) and thus S. maltophilia was identified. No agents were detected in mycological culture (BD Bioscience ${ }^{\circledR}$, New Jersey, USA). In order to identify S. maltophilia and to rule out mycological factors, enriched soybean-casein digest broth was used as a medium. Aerobic atmosphere enriched with $\mathrm{CO}_{2}$. This medium was preferred according to the manufacturer's instructions as the cat was already under antimicrobial therapy. The recommended blood volume for the culture is 3-10 $\mathrm{ml}$. For this reason, $3 \mathrm{ml}$ of blood was used. Before adding blood, the medium was checked for turbidity and the septum was cleaned with alcohol. After adding blood, the vial was placed on the $\mathrm{BD}{ }^{\circledR}$ fluorescence device immediately at room temperature. Results were obtained after 36 hours.
Resin concentration for nonionic adsorbing resin was $16.0 \% \mathrm{w} / \mathrm{v}$ and for cationic exchange resin was $1.0 \% \mathrm{w} / \mathrm{v}$.

It was determined that the agent was resistant to several antibiotics including tylosin, imipenem, meropenem, cefuroxime, ampicillin, tigecycline and cephalexin on the basis of the antibiogram performed by disc diffusion method. However, it was susceptible to some antibiotics including oxytetracycline, enrofloxacin, moxifloxacin, trimethoprim-sulfamethoxazole and kanamycin. The complete antibiogram is presented in Table 2. 
Table 2 The complete list of antibiogram result

\begin{tabular}{lll}
\hline \multicolumn{1}{c}{ Resistant } & \multicolumn{1}{c}{ Intermediate } & \multicolumn{1}{c}{ Susceptible } \\
\hline $\begin{array}{l}\text { Ertapenem, Imipenem, Meropenem, Cefazolin, } \\
\text { Cefuroxime, Ceftazidime, Cephalexin, }\end{array}$ & Cefepime, & Amikacin, Gentamicin, \\
Ceftriaxone, Ceftolozane-Tazobactam, & Neomycin & Colistin,Trimethoprim- \\
Ampicillin, Amoxicillin-clavulanate (f), & & sulfamethoxazole,Levofloxacin, \\
Ampicillin-sulbactam (f), Amoxicillin & & Oxytetracyclin, Enrofloxacin, \\
Piperacillin-tazobactam, Tigecycline, Tylosin & & Kanamycin, Moxifloxacin \\
\hline
\end{tabular}

Regarding to the analysis results, a treatment protocol including enrofloxacin (Baytril, Bayer) at a dose of $5 \mathrm{mg} / \mathrm{kg}$, BID, ambroxol (Sekrol, Bilim Pharmaceuticals) at a dose of $1 \mathrm{mg} / \mathrm{kg}$, TID and oxymetazoline $0.05 \%$, BID (Iliadin, Merck) was administrated. The treatment period was planned for 12 days. After the $7^{\text {th }}$ day of the treatment period, the cat was re-evaluated. Via communication with the owner, it was ascertained that all clinical findings disappeared from the $4^{\text {th }}$ day of treatment and the appetite returned to normal. Physical examination on the $7^{\text {th }}$ day of the treatment period revealed no abnormalities (body temperature: 38.7 ${ }^{\circ} \mathrm{C}$, heart rate: 144 beats $/ \mathrm{min}$, respiration rate: 60 breaths/min). Blood gases, hemogram and serum biochemistry parameters were within the reference range (Table 3). No abnormality was detected in the thoracic x-ray (Figure 1B).

Table 3 Blood gases, hematology and serum biochemistry results (follow-up)

\begin{tabular}{|c|c|c|c|c|c|c|c|c|}
\hline \multicolumn{2}{|c|}{ Blood Gases } & \multirow{2}{*}{$\begin{array}{l}\text { Reference* }^{*} \\
7.35-7.45\end{array}$} & \multicolumn{2}{|c|}{ Hematology } & \multirow{2}{*}{$\begin{array}{c}\text { Reference } \\
5.0-19.0 \\
\end{array}$} & \multicolumn{2}{|c|}{ Serum Biochemistry* } & \multirow{2}{*}{$\begin{array}{c}\text { Reference } \\
4.7-14.3\end{array}$} \\
\hline $\mathrm{pH}$ & 7.43 & & WBC $10^{9} / \mathrm{L}$ & 7.20 & & BUN mg/dL & 8.8 & \\
\hline $\mathrm{pO}_{2}$ & 6.7 & $46.0-55.0$ & Lym\# 109/L & 2.65 & $0.2-5.7$ & nine $m$ & 0.9 & $0.8-1.80$ \\
\hline $\mathrm{pCO}_{2}$ & 36.6 & $29.0-42.0$ & Mon \# 109/L & 0.86 & $0.1-1.1$ & $\mathrm{U} / \mathrm{L}$ & 34 & 10 \\
\hline $\mathrm{satO}_{2}$ & 81 & $78-86$ & Gra \# 109/L & 3.69 & $2.0-15.2$ & ALP U/L & 76 & $10-80.00$ \\
\hline $\mathrm{K} \mathrm{mmol} / \mathrm{L}$ & 4.1 & $3.4-5.6$ & $\mathrm{RBC} 10^{12} / \mathrm{L}$ & 5.67 & $4.0-9.0$ & ALT U/L & 44 & $10-80.00$ \\
\hline $\mathrm{Na} \mathrm{m}$ & 161 & 65 & $\mathrm{M}$ & 48.3 & 5.0 & A & 3.1 & 2. \\
\hline $\mathrm{Cl} \mathrm{mmol/L}$ & 109 & $104-128$ & $\mathrm{MCH}$ & 19.7 & $16.0-24.0$ & Trig $\mathrm{mg} / \mathrm{dL}$ & 98 & $10-114.0$ \\
\hline $\mathrm{Lac} \mathrm{mmol} / \mathrm{L}$ & 0.8 & $0-2$ & $\mathrm{MCH}$ & 33.4 & $28.0-40.0$ & T. protein $\mathrm{g} / \mathrm{dL}$ & 6.6 & $5.4-7.80$ \\
\hline $\mathrm{BE} \mathrm{mmol} / \mathrm{L}$ & -4.6 & $-4-4$ & Hct & 38.9 & $24.0-45.0$ & Cholest. mg/dL & 155 & $90-205$ \\
\hline $\mathrm{HCO}_{3}$ & 22.2 & $19-24$ & RDW & 10.1 & $8.0-12.0$ & Glucose mg/dL & 98 & $64-170$ \\
\hline
\end{tabular}

pH: Power of hydrogen, pO2: Partial pressure of oxygen, pCO2: Partial pressure of carbon dioxide, satO2: Oxygen saturation, K: Potassium, Na: Sodium, Cl: Chlorine, Lac: Lactate, BE: Base excess, HCO3: Bicarbonate, WBC: White blood cells, Lym: Lymphocytes, Mon: Monocytes, Gra: Granulocytes, RBC: Red blood cells, MCV: Mean corpuscular volume, MCH: Mean corpuscular hemoglobin, MCHC: Mean corpuscular hemoglobin concentration, Hct: Hematocrit, RDW: red cell distribution width, BUN: Blood urea nitrogen, AST: Aspartate aminotransferase, ALP: Alkaline phosphatase, ALT: Alanine aminotransferase, Trig: Trigylcerides, T.protein: Total protein, Cholest: Cholesterol. Units and reference values are based on *Klaassen, 1999 and $\$$ Moritz et al., 2004 

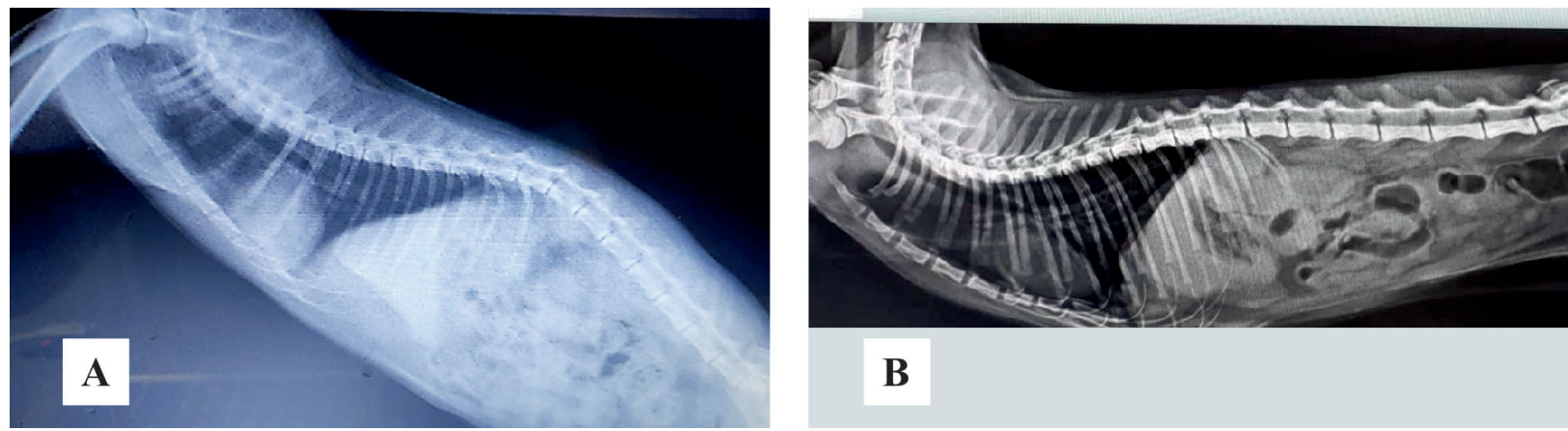

B

\section{Figure 1}

Thoracic x-ray on first admission (A) and follow up (B)

\section{DISCUSSION AND CONCLUSION}

In respiratory diseases of cats, signalment and lifestyle (indoor/outdoor) usually help to establish a differential diagnosis list and direct diagnostic work-up. While neoplasia and polyps are more common in older cats, exposure to foreign bodies, trauma and infectious etiologies are more common in outdoor cats (Henderson et al., 2004; Quimby and Lappin, 2009) and flat-faced breeds including Scottish Folds (Kornreich et al., 2012).

Stenotrophomonas maltophilia, which can be found in almost all aquatic and humid environments, can survive and multiply in the body, respiratory secretions, urine and intravenous fluids (Falagas et al., 2009). It has been reported that $S$. maltophilia can cause endocarditis, pneumonia, bone and joint infections as well as urinary tract infections (Kralova-Kovarikova et al., 2012). In humans, it is reported that the transmission is mostly hospital-acquired. Also, long hospitalization period, venous and/or urinary catheterization, peritoneal dialysis and nasal cannula applications can facilitate transmission (Al-Anazi and AlJasser, 2014). According to the cat's lifestyle and previous treatment with oxygen therapy, possible routes of transmissions in this case were contamination from outdoors or from nasal cannula. S. maltophilia is intrinsically resistant to carbapenems, aminoglycosides, most thirdgeneration cephalosporins and other beta-lactams. It is also known to be susceptible to trimethoprimsulfamethoxazole, fluoroquinolones, polymyxin B and rifampicin (Falagas et al., 2009; Al-Anazi and Al-Jasser, 2014). In this case report, on the basis of the antibiogram performed by disc diffusion method, it was determined that the agent was resistant to amoxicillin, tylosin, imipenem, meropenem, cefuroxime, ampicillin, tigecycline, cephalexin, and susceptible to oxytetracycline, enrofloxacin, moxifloxacin, trimethoprimsulfamethoxazole and kanamycin in accordance with previous reports (Denton and Kerr, 1998; Falagas et al., 2009). Failure of empirical clavulanic acid and amoxicillin trihydrate administration in the previous treatment is associated with the intrinsic resistance (endogenous $\beta$-lactamase production) of the agent to this group of antibiotics (Petridou et al., 2010). Although trimethoprimsulfamethoxazole was the first choice antibiotic in previous reports (Kralova-Kovarikova et al., 2012; 
Falagas et al., 2009), enrofloxacin was preferred in the present case due to the reported resistance increase (Al-Anazi and Al-Jasser, 2014).

In veterinary medicine and veterinary diagnostic laboratory routine, S. maltophilia infection is probably underdiagnosed as a selective medium is not used for bacterial culture. Isolation, identification and antibiotic susceptibility testing of this multidrug-resistant bacterium is clinically important, especially in patients with chronic respiratory disease and long hospitalization periods (Petridou et al., 2010; Al-Anazi and AlJasser, 2014). Although it is a well-known fact that PCR analysis is superior to culture identification (such as Mueller-Hinton Agar, tryptone soy agar with 5\% sheep blood and enriched soybean-casein digest broth), it was stated by several authors that aerobic cultures of the respiratory tract secretions could also be used in order to identify S. maltophilia (Whitby et al., 2000; Al-Jasser, 2006). That is, in suboptimal conditions, aerobic culture method could be preferred as an alternative method for identification of the agent as in the present case.

Stenotrophomonas maltophilia was isolated from nasal discharge in a cat with persistent chronic respiratory disease characterized by sneezing and both nasal and ocular discharge and was successfully treated with enrofloxacin, which was determined to be susceptible on by the antibiogram. As a result, it was concluded that $S$. maltophilia should be considered in the etiology of persistent, antibiotic-resistant chronic respiratory diseases of cats, and that the antibiogram and agent isolation were important in the diagnosis.

\section{ACKNOWLEDGEMENT}

None.

\section{CONFLICT OF INTEREST}

The authors declared that there are no conflicts of interest. 


\section{REFERENCES}

Al-Anazi KA, Al-Jasser AM.2014. Infections caused by Stenotrophomonas maltophilia in recipients of hematopoietic stem cell transplantation. Front Oncol, 4, 232. doi: 10.3389/ fonc. 2014.00232

Albini S, Abril C, Franchini M, Hussy D, Filipoussis G. 2009. Stenotrophomonas maltophilia isolated from the airways of animals with chronic respiratory disease. Schweiz Arch Tierheilkd, 151(7), 323-8. doi: 10.1024/0036-7281.151.7.323

Al-Jasser AM. 2006. Stenotrophomonas maltophilia resistant to trimethoprim-sulfamethoxazole: an increasing problem. Ann Clin Microbiol Antimicrob, 18(5), 23. doi: 10.1186/14760711-5-23

Bannasch MJ, Foley JE. 2005. Epidemiologic evaluation of multiple respiratory pathogens in cats in animal shelters. J Feline Med Surg, 7(2), 109-19. doi: 10.1016/j. jfms.2004.07.004

Cloud-Hansen KA, Villiard KM, Handelsman J, Carey HV. 2007. Thirteen-lined ground squirrels (Spermophilus tridecemlineatus) harbor multiantibiotic-resistant bacteria. J Am Assoc Lab Anim Sci, 46(3), 21 -3.

Demko JL, Cohn LA. 2007. Chronic nasal discharge in cats: 75 cases (1993-2004). Javma-J Am Vet Med A, 230(7), 10327. doi: $10.2460 /$ javma.230.7.1032

Denton M, Kerr KG. 1998. Microbiological and clinical aspects of infection associated with Stenotrophomonas maltophilia. Clin Microbiol Rev, 11(1), 57-80. doi: 10.1128/ CMR.11.1.57

Falagas ME, Kastoris AC, Vouloumanou EK, Dimopoulos G. 2009. Community-acquired Stenotrophomonas maltophilia infections: a systematic review. $\quad$ Eur J Clin Microbiol Infect Dis, 28(7), 719-30. doi: 10.1007/s10096-009-0709-5

Henderson SM, Bradley K, Day MJ, Tasker S, Caney SMA, Moore AH, et al. 2004. Investigation of nasal disease in the cat - a retrospective study of 77 cases. J Feline Med, 6(4), 245-57. doi: 10.1016/j.jfms.2003.08.005
Klaassen JK. 1999. Reference Values in Veterinary Medicine. Lab Med, 30(3), 194-7.

Kornreich BG, Kraus MS, McEntee MC, Miller WH, Rodan I. 2012. The First Clue: a Persistent Cough. http:/ theanimalhospitable.com/storage/app/media/Dog-catwatch/ CatWatch2012/catwatch-2012-11.pdf (accesed 10.15.21.)

Kralova-Kovarikova S, Husnik R, Honzak D, Kohout P, Fictum P. 2012.Stenotrophomonas maltophilia urinary tract infections in three dogs: a case report. Vet Med, 57(7), 380-3.

Moritz A, Fickenscher Y, Meyer K, Failing K, Weiss DJ. 2004. Canine and feline hematology reference values for the ADVIA120 hematology system. Vet Clin Pathol, 33(1), 32-8.

O'Brien CR, Krockenberger MB, Wigney DI, Martin P, Malik R. 2004. Retrospective study of feline and canine cryptococcosis in Australia from 1981 to 2001: 195 cases. Med Mycol, 42(5), 449-60.

Petridou E, Filioussis G, Karavanis E, Kritas SK. 2010. Stenotrophomonas maltophilia as a causal agent of pyogranulomatous hepatitis in a buffalo (Bubalus bubalis). J Vet Diagn Invest, 22(5), 772-4. doi: $10.1177 / 104063871002200522$

Quimby J, Lappin M. 2009. Feline focus: Update on feline upper respiratory diseases: introduction and diagnostics. Compend (Yardley, PA), 31(12), 1-7.

Richter M, Schudel L, Tobler K, Matheis F, Vögtlin A, Vanderplasschen A, et al. 2009. Clinical, virological, and immunological parameters associated with superinfection of latently with FeHV-1 infected cats. Vet. Microbiol, 138(3-4), 205-16. doi: 10.1016/j.vetmic.2009.03.022

Whitby PW, Carter KB, Burns JL, Royall JA, LiPuma JJ, Stull TL. 2000. Identification and detection of Stenotrophomonas maltophilia by rRNA-directed PCR. J Clin Microbiol, 38(12), 4305-9. doi:10.1128/JCM.38.12.4305-4309.2000 


\section{STENOTROPHOMONAS MALTOPHILIA KAO UZROČNIK HRONIČNE RESPIRATORNE BOLESTI KOD MAČKA VRSTE ŠKOTSKI FOLD: PRIKAZ SLUČAJA}

\section{SAŽETAK}

Kihanje i iscjedak iz nosa su česte pojave kod mačaka koje boluju od respiratornih bolesti. Bakterije, virusi i gljivice igraju ulogu u etiologiji respiratornih oboljenja. Iako je Stenotrophomonas maltophilia (S. maltophilia) prihvaćena kao bezopasni komensal i kolonizator zbog svog ponašanja koje ne izaziva niti imuni odgovor niti kliničke simptome, izolirana je iz životinja koje boluju od hroničnih respiratornih bolesti. U našem prikazu slučaja prikazujemo identifikaciju i terapiju za $S$ maltophilia kod mačka sa hroničnom respiratornom bolešću koja nije izliječena upotrebom empirijske antibiotske terapije. Fizikalni pregled mačka je pokazao uredne vitalne parametre i naglašen obostrani mukopurululentni iscjedak iz nosa. Rezultati krvih pretraga su bili uredni osim blage respiratorne acidoze, limfocitoze i povišene enzimatske aktivnosti alkalne fosfataze. Nakon što su isključene gljivična i sistemska virusna infekcija, na temelju aerobne kulture je izoliran uzročnik. Potpuni oporavak je postignut primjenom terapijskog protokola koji uključuje sekretolitik (ambroxol, $1 \mathrm{mg} / \mathrm{kg}$ ), dekongestant (oxymetazoline, 0.05\%) i antibiotik (enroflaxacin, $5 \mathrm{mg} / \mathrm{kg}$ ) čija se aplikacija temeljila na rezultatima antibiograma koji je dobijen metodom difuzije diska (MuellerHintonov agar). Na kontrolnim pregledima su svi klinički i krvni parametri bili uredni. Stoga je zaključeno da je potrebno uzeti u obzir S. maltophilia kao uzročnika u etiologiji perzistirajućih rezistentnih hroničnih respiratornih bolesti mačaka i da su antibiogram i identifikacija uzročnika važni za postavljanje konačne dijagnoze.

Ključne riječi: Hronična respiratorna bolest, kolonizator, mačka, Stenotrophomonas maltophilia, terapija 